\title{
Erratum: Speech Characteristics of Patients with Parkinson's Disease-Does Dopaminergic Medications Have a Role?
}

Valiyaparambath Purushothaman Vandana ${ }^{1}$ Jeevendra Kumar Darshini ${ }^{1}$ Venkappayah Holla Vikram ${ }^{2}$ Kamble Nitish ${ }^{2}$ Pramod Kumar Pal ${ }^{2}$ Yadav Ravi

\footnotetext{
${ }^{1}$ Department of Speech Pathology and Audiology, National Institute of Mental Health and Neurosciences (NIMHANS), Bengaluru, Karnataka, India

2 Department of Neurology, National Institute of Mental Health and Neurosciences (NIMHANS), Bengaluru, Karnataka, India
}

J Neurosci Rural Pract 2021;12:e1.
Address for correspondence Vandana Valiyaparambath Purushothaman, PhD, Department of Speech Pathology and Audiology, National Institute of Mental Health and Neurosciences (NIMHANS), Bengaluru, Karnataka, 560029, India (e-mail: vpvandana@gmail.com).
ERRATUM
It has been brought to the publisher's attention that the name of the author "Pramod Kumar Pal" was incorrectly set in the article (DOI: 10.1055/s-0041-1735249), published in the issue number 4, volume 12, of the Journal of Neurosciences in Rural Practice. The correct name appears as above.
DOI https://doi.org/ $10.1055 / \mathrm{s}-0042-1743280$. ISSN 0976-3147. (c) 2022. Association for Helping Neurosurgical Sick People. All rights reserved.

This is an open access article published by Thieme under the terms of the Creative Commons Attribution-NonDerivative-NonCommercial-License, permitting copying and reproduction so long as the original work is given appropriate credit. Contents may not be used for commercial purposes, or adapted, remixed, transformed or built upon. (https://creativecommons.org/ licenses/by-nc-nd/4.0/)

Thieme Medical and Scientific Publishers Pvt. Ltd., A-12, 2nd Floor, Sector 2, Noida-201301 UP, India 